CHINA FROM EMPIRE TO NATION-STATE 



\section{China from Empire to Nation-State}

WANG HUI

Translated by

MICHAEL GIBBS HILL

II Harvard University Press

Cambridge, Massachusetts

London, England

2014 
Copyright $\odot 2014$ by the President and Fellows of Harvard College

All rights reserved

Printed in the United States of America

First printing

Originally published as the Introduction to Zhongguo xiandai siziangde xingqi, 2004, 2008 by SDX Joint Publishing Company, Beijing.

\section{Library of Congress Cataloging-in-Publication Data}

Wang, Hui, 1959-

[Di guo yu guo jia. English]

China from empire to nation-state / Wang Hui ; translated by Michael Gibbs Hill. pages $\mathrm{cm}$

Includes bibliographical references and index.

ISBN 978-0-674-04695-5 (alk. paper)

1. China-Civilization-Philosophy. I. Title.

DS721.W337 135132014

951-dc23 